\title{
Human-Robot Interaction and Sexbots: A Systematic Literature Review
}

\author{
Carina Soledad González-González ${ }^{1, * \mathbb{D}}$, Rosa María Gil-Iranzo ${ }^{2} \mathbb{D}$ and Patricia Paderewski-Rodríguez ${ }^{3}$ (D) \\ 1 Departamento de Ingeniería Informática y de Sistemas, Escuela de Ingeniería y Tecnología, \\ Universidad de La Laguna, 38204 La Laguna, Spain \\ 2 Departamento de Informática e Ingeniería Industrial, Escuela Politécnica Superior, Universitat de Lleida, \\ 25001 LLeida, Spain; rgil@diei.udl.cat \\ 3 Departmento de Lenguajes y Sistemas Informáticos, Escuela Técnica Superior de Ingenierías Informática y de \\ Telecomunicación, Universidad de Granada, 18071 Granada, Spain; patricia@ugr.es \\ * Correspondence: carina.gonzalez@ull.edu.es
}

check for updates

Citation: González-González, C.S.; Gil-Iranzo, R.M.; Paderewski-Rodríguez, P. Human-Robot Interaction and Sexbots: A Systematic Literature Review. Sensors 2021, 21, 216. https://doi.org/10.3390/s21010216

Received: 21 October 2020 Accepted: 26 December 2020 Published: 31 December 2020

Publisher's Note: MDPI stays neutral with regard to jurisdictional clai$\mathrm{ms}$ in published maps and institutional affiliations.

Copyright: (C) 2020 by the authors. Licensee MDPI, Basel, Switzerland. This article is an open access article distributed under the terms and conditions of the Creative Commons Attribution (CC BY) license (https:// creativecommons.org/licenses/by/ $4.0 /)$.

\begin{abstract}
At present, sexual robots have become a new paradigm of social robots. In this paper, we developed a systematic literature review about sexual robots (sexbots). To do this, we used the Scopus and WoS databases to answer different research questions regarding the design, interaction, and gender and ethical approaches from 1980 until 2020. In our review, we found a male bias in this discipline, and in recent years, articles have shown that user opinion has become more relevant. Some insights and recommendations on gender and ethics in designing sexual robots were also made.
\end{abstract}

Keywords: sexual robots; ethics; gender; social robots; human-robot interaction; sexbots

\section{Introduction}

Recently, the area of human-robot interaction (HRI) [1], particularly in relation to sexual robots, has begun to attract interest with regard to various social issues, such as emotions, ethics, philosophy, and psychology. These new relationships between sexual robots and humans have also awakened the interest of the media [2], the industry, and the maker world, since with a 3D printer, it is already possible to create a sexual robot [3]. Society has begun to consider the idea of having sex with robots, and there is the belief that this will be normal in the future [4]. Although there is still no scientific evidence of its therapeutic benefits, many think it can help treat sexual dysfunctions or even help decrease women's sexual exploitation. Like sex toys, some experts consider sexual robots (or sexbots) to have potential in being the future of sex relationships [2].

However, there are many unanswered questions about the relationships between these types of social robots and people, i.e., about their safety, about how they affect the "psychological aspects", about the legal regulations for their use, as, for example, in the case of child sex robots. Therefore, in this paper, we will try to answer the following questions:

RQ1: How are sexbots designed?

RQ2. How do sexbots interact with humans?

RQ3: What gender and ethical issues are related to the design and use of sexbots?

Regarding RQ1, we aim to prove the hypothesis that the design of sexbots is driven not by academic research, but only by the market. This implies that moral issues are not necessarily included. This first question highlights the point that academic research is not used in the design of these sexbots. We wanted to prove that the parameters taken from male preferences are used the most in the design. The second question, RQ2, is about our concern in the kind of relationships that can be established between sexbots and humans. We set out to explore whether these relationships would be healthy. The third question, RQ3, is related to our hypothesis that the design of sexbots does not begin (usually) from the viewpoint of protecting human values. 
Thus, in this paper, we conduct a systematic review to answer the mentioned questions, focusing on the ethical and gender approaches about sex with robots. The paper is organized in several different sections. Section 2 presents some current sexbots that are available in the market. Section 3 presents the method followed, and the results are presented in Section 4. Section 5 discusses the obtained results regarding the research questions. Specifically, the process of sexbot design, the interactions with humans, and gender and ethical issues are discussed. Finally, conclusions are presented to provide a roadmap for the designers of sexual robot technology.

\section{Background}

The realism of the sex dolls has increased over the years. We begin by comparing their evolution from the 17th century, where such dolls were first made of fabric, to those in the 1970s made of latex, silicone, and inflatables, and lastly to the sophisticated models with artificial intelligence today. We can see that the market has changed greatly [5]. In this section, we present some of the current models of sexbots.

To date, there is no consensus on a unique definition of sexual robots, also known as sexbots [6]. We can compare sexbots to sex toys because both are created to have sex with humans [7]. However, sexbots can cause emotions in people, such as love [8]. There are different research areas interested in exploring these new relations among sexbots and humans [9-14].

Sexbots are a kind of social robots, ones that are personalized, intimate companions. In most cases, sexbots are personalized according to male fantasies. However, both men and women can acquire different models in the market, such as Roxxxy [10], Harmony [11] (Figure 1), or Henry [12] (Figure 2).

Designers of sexbots need to consider the temperature, the psychological and physical issues, among other customizable elements [5]. In addition, some of these sexbots also have a certain intelligence [13]. They can be a reactive machine (i.e., perceive the world and act in consequence), have memory, be based on mind theories, or have self-awareness. In the last case, robots with self-awareness can be considered a sentient robot.

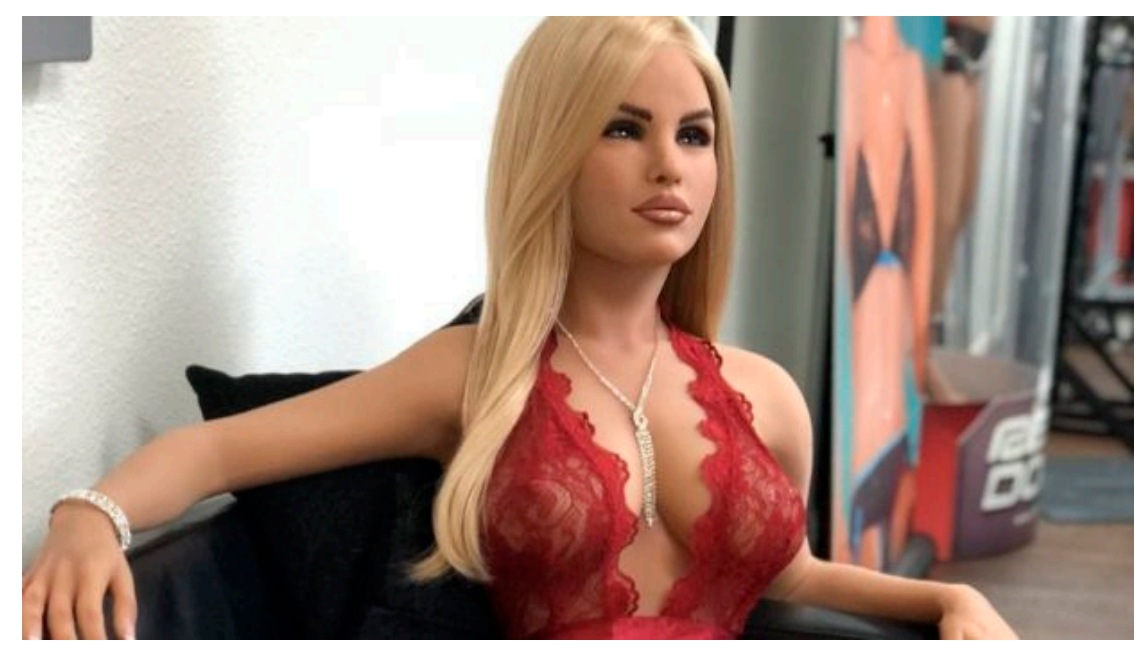

Figure 1. Harmony, marketed as "the perfect companion" with artificial intelligence (Source: http: //www.sickchirpse.com/biggest-worry-men-sex-robots/). 

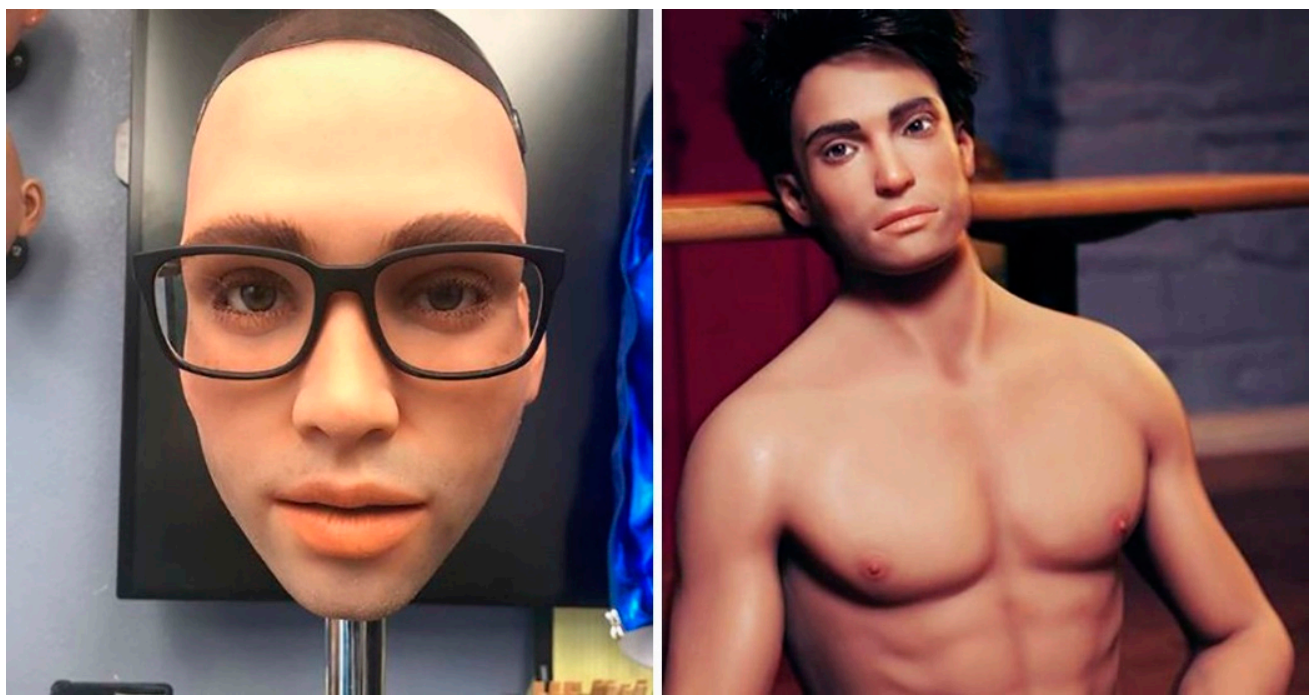

Figure 2. Henry, male version with artificial intelligence (https:/ / realbotix.com/).

In the next section, we will describe the systematic review that we conducted about sexual robots and their implications for humans.

\section{Materials and Methods}

This article focuses on indexed and peer-reviewed journal articles about sexbots, sexual robots, and sex dolls that were published between 1980 and 2020. A search was conducted in the Web of Science (WoS) and Scopus databases during September 2020 to locate papers on computers, robotics, behavioral sciences, psychology, science, social science, and other topics. An advanced search was conducted using specific terms (i.e., sex AND doll OR sexual robots OR sexbot).

We did several tries in different periods, but no meaningful documents were obtained out of the defined time interval. On the search terms, they are words that are usually related to machines (understood as robots) and sex in interactive systems design, concretely in engineering. The relevant areas for us were related to the designers of this kind of robot, not only in the software but also in the hardware. We found that the article type is the most common way to communicate the latest research with a certain guarantee of scientific quality (peer-reviewed) for the type of papers we selected.

The three authors in this study independently completed an inclusion/exclusion checklist to ensure the systematic review's reliability while screening the titles, keywords, and abstracts of the primary search. A qualitative analysis was conducted using a consensus agreement method to resolve any differences.

The inclusion criteria were the following: The type of document must be an article, with English as the chosen language; the period of publication must be between 1980 and 2020, the research topics of the articles must be on either computers, robotics, behavioral sciences, psychology, science, social science, or any other related topics. The exclusion criteria were the following: The study could not be retrieved; the type of article contains opinions or is editorial in type; the article is not related to robots; and the article is neither in English nor in Spanish. The articles were then categorized into three categories: (a) articles excluded due to the exclusion criteria being met; (b) articles excluded due to the inclusion criteria being only partially met with sexbots or robotics; and (c) articles included due to the inclusion criteria being fully met.

We made our analysis based on IEEE P7008 - the Standard for Ethically Driven Nudging for Robotic, Intelligent, and Autonomous Systems. Sponsored by the IEEE Robotics and Automation Society, IEEE P7008 delineates the concepts, functions, and benefits necessary to establish and ensure ethically driven methodologies for the design of robotic, intelligent, and autonomous systems following worldwide ethics and moral theories, with 
an emphasis on aligning the ethics and engineering communities to understand how to pragmatically design and implement these systems. However, it is still under development, which is the reason we have not validated it against a standard.

\section{Results}

The search in WoS using the keywords and the period between 1980 and 2020 resulted in 1244 articles. After filtering by the type of document for results where the document is an article, 1002 papers remained. These 1002 papers were then filtered by topics following the inclusion criteria, and this resulted in 536 papers. After screening the titles and keywords, 55 papers remained for the screening of the abstracts.

To have an overview of our database and refine it properly afterward, we performed a series of bibliometric measures on the WoS database with topics that we think are appropriate, as shown in Figure 3.

\begin{tabular}{l|l|l}
\hline$\square$ PSYCHOLOGY DEVELOPMENTAL (21) & $\square$ MEDICINE RESEARCH EXPERIMENTAL (3) & $\square$ CRIMINOLOGY PENOLOGY (1) \\
$\square$ PSYCHOLOGY MULTIDISCIPLINARY (13) & $\square$ NEUROSCIENCES (3) & $\square$ EDUCATION SPECIAL (1) \\
$\square$ PSYCHOLOGY EXPERIMENTAL (12) & $\square$ PSYCHIATRY (3) & $\square$ ENGINEERING BIOMEDICAL (1) \\
$\square$ PSYCHOLOGY SOCIAL (8) & $\square$ PSYCHOLOGY EDUCATIONAL (3) & $\square$ ENGINEERING ELECTRICAL ELECTRONIC (1) \\
$\square$ SOCIOLOGY (8) & $\square$ SOCIAL SCIENCES INTERDISCIPLINARY (3) & $\square$ ENVIRONMENTAL SCIENCES (1) \\
$\square$ MULTIDISCIPLINARY SCIENCES (6) & $\square$ SOCIAL WORK (3) & $\square$ HISTORY PHILOSOPHY OF SCIENCE (1) \\
$\square$ ROBOTICS (6) & $\square$ PHARMACOLOGY PHARMACY (2) & $\square$ INFORMATION SCIENCE LIBRARY SCIENCE (1) \\
$\square$ WOMEN S STUDIES (6) & $\square$ PHILOSOPHY (2) & $\square$ LAW (1) \\
$\square$ ETHICS (5) & $\square$ ANTHROPOLOGY (1) & $\square$ MEDICAL ETHICS (1) \\
$\square$ COMPUTER SCIENCE ARTIFICIAL INTELLIGENCE (4) & $\square$ BIOCHEMICAL RESEARCH METHODS (1) & $\square$ PSYCHOLOGY BIOLOGICAL (1) \\
$\square$ COMPUTER SCIENCE CYBERNETICS (4) & $\square$ COMPUTER SCIENCE INFORMATION SYSTEMS (1) & $\square$ PSYCHOLOGY CLINICAL (1) \\
$\square$ FAMILY STUDIES (4) & $\square$ COMPUTER SCIENCE INTERDISCIPLINARY APPLICATIONS (1) & $\square$ PUBLIC ENVIRONMENTAL OCCUPATIONAL HEALTH (1) \\
$\square$ ERGONOMICS (3) & $\square$ COMPUTER SCIENCE THEORY METHODS (1) & $\square$ REHABILITATION (1)
\end{tabular}

Figure 3. Topics selected in Web of Science (WoS) database.

We followed the same procedure in the Scopus database with the following results, using the same query (i.e., TITLE-ABS-KEY: sexbot* OR sexual AND robot* OR sex AND doll), which gave us 75 documents. With the filter per year (1980-2020), 73 documents were found. After that, only the articles were selected, which were 54 documents. After the documents were filtered by area, i.e., psychology, social sciences, arts and humanities, computer science, and engineering, 44 documents were selected. The documents that were not related to our investigation were eliminated from the list. After cleaning for duplicates, we added 10 papers to the list of papers to analyze. Finally, we screened the abstracts, as well as 28 papers in the WoS and 9 of Scopus for the full-text analysis. Thus, the total number of papers that met the inclusion criteria for the full-text analysis was 31 .

The flow diagram of our study was designed following the recommendations of the Preferred Reporting Items for Systematic Reviews and Meta-Analyses (PRISMA [15]) (Figure 4).

In trying to know which authors influence the topics we are interested in, we created a 3-plot diagram in order to draw a relation among the references, authors, and topics (Figure 5). This figure allowed us to find the connection between which authors made the knowledge basis and how journals elaborate the semantics. The words became the metadata with which we could use to search, and they are representative of the topics. 


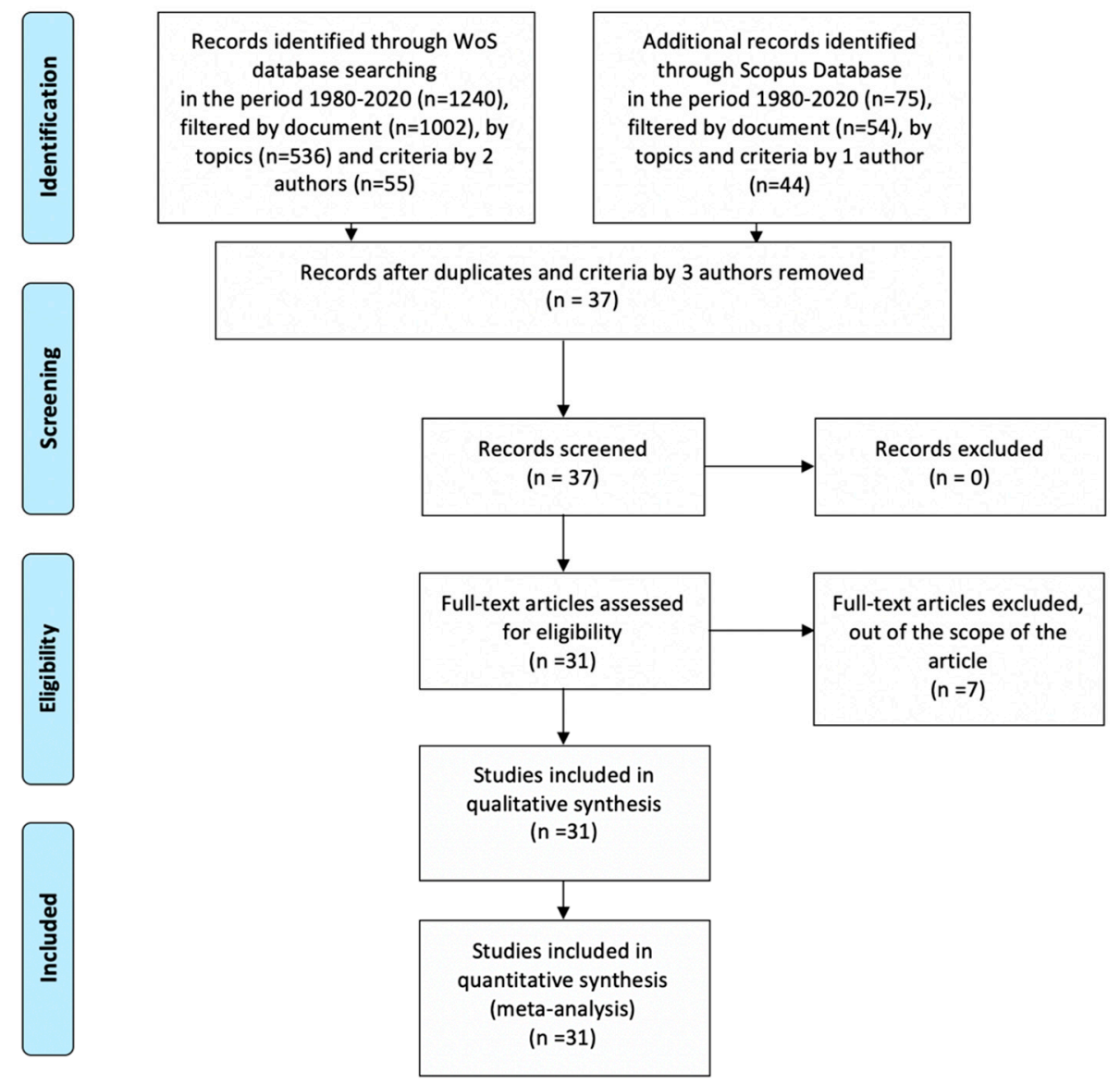

Figure 4. Flow diagram of the study selection process PRISMA (Preferred Reporting Items for Systematic Reviews and Meta-Analyses).

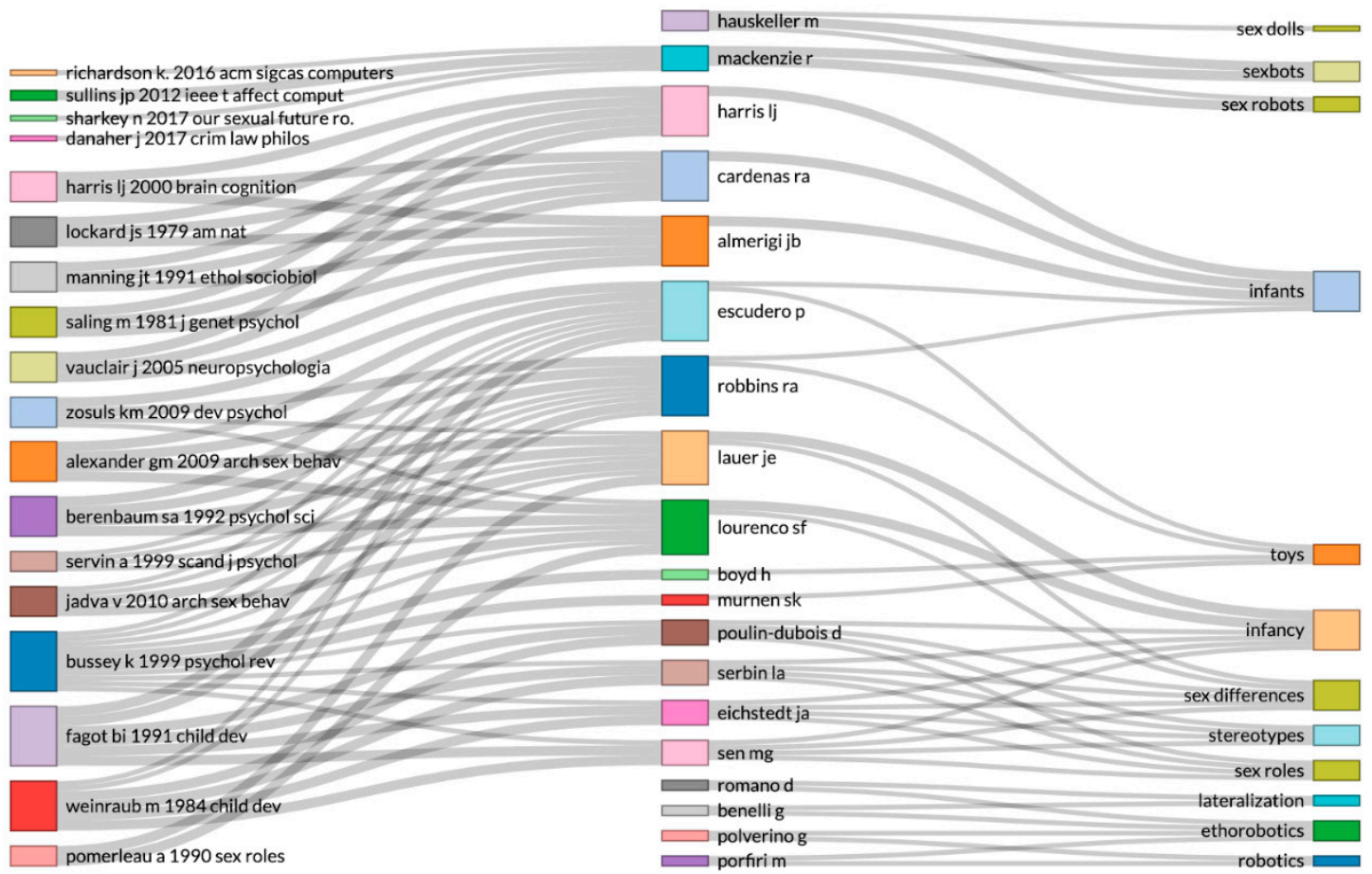

Figure 5. Three-plot diagram relating the references, authors, and topics. This diagram also shows who the authors were that built a concrete term. 
Another question that we wanted to know was which time period is the most prolific one. It seems that 2010 marks the beginning of such a period (Figure 6). This kind of graphic allowed us to visualize the density of the activity periods of the chosen authors. Thus, it can be established when the concrete time window is when searching for information.

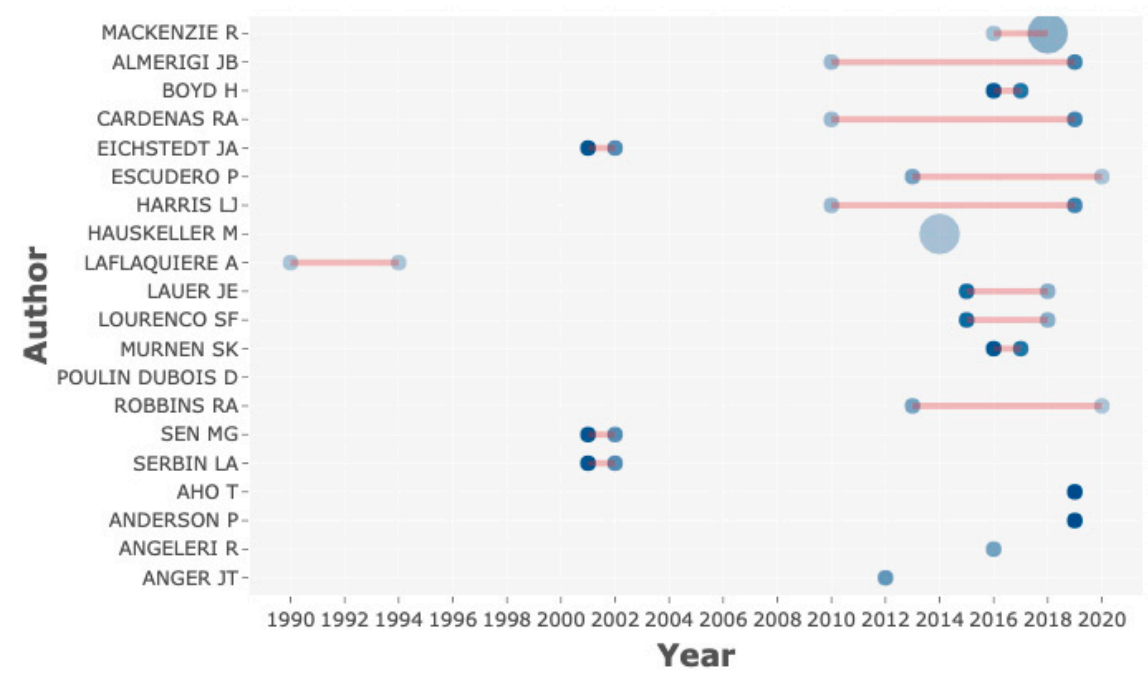

Figure 6. Comparison of the periods of publications according to author search.

We also wondered about the terms associated with our search (i.e., TITLE-ABS-KEY: sexbot* OR sexual AND robot* OR sex AND doll), so we constructed some CloudWords with titles, and we found some unexpected topics, such as mothers and children (Figure 7). This technique emphasizes which terms are the most used, the size, and the position fix, which is relevant.

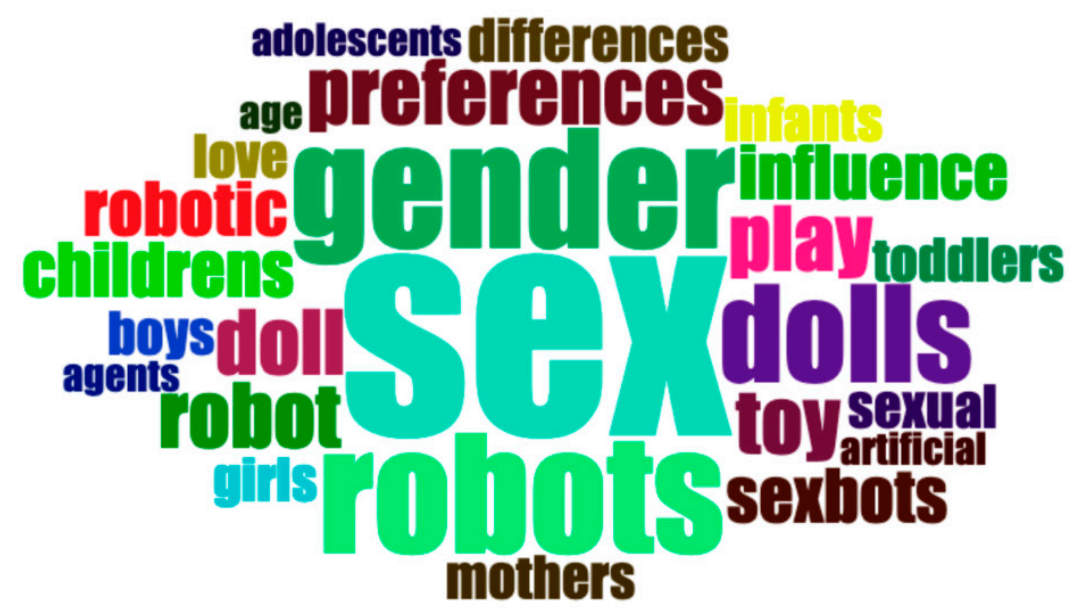

Figure 7. CloudWords with titles of papers found in the review.

We analyzed the co-occurrence network, using edge betweenness as a clustering algorithm, to figure out which concepts were more used and whether they were related (Figure 8). This figure was realized in order for us to look for concepts that we did not consider in our analysis, and they could be interesting concepts to be taken into account in further analysis. Some concepts were not expected, such as play behavior or constancy. 


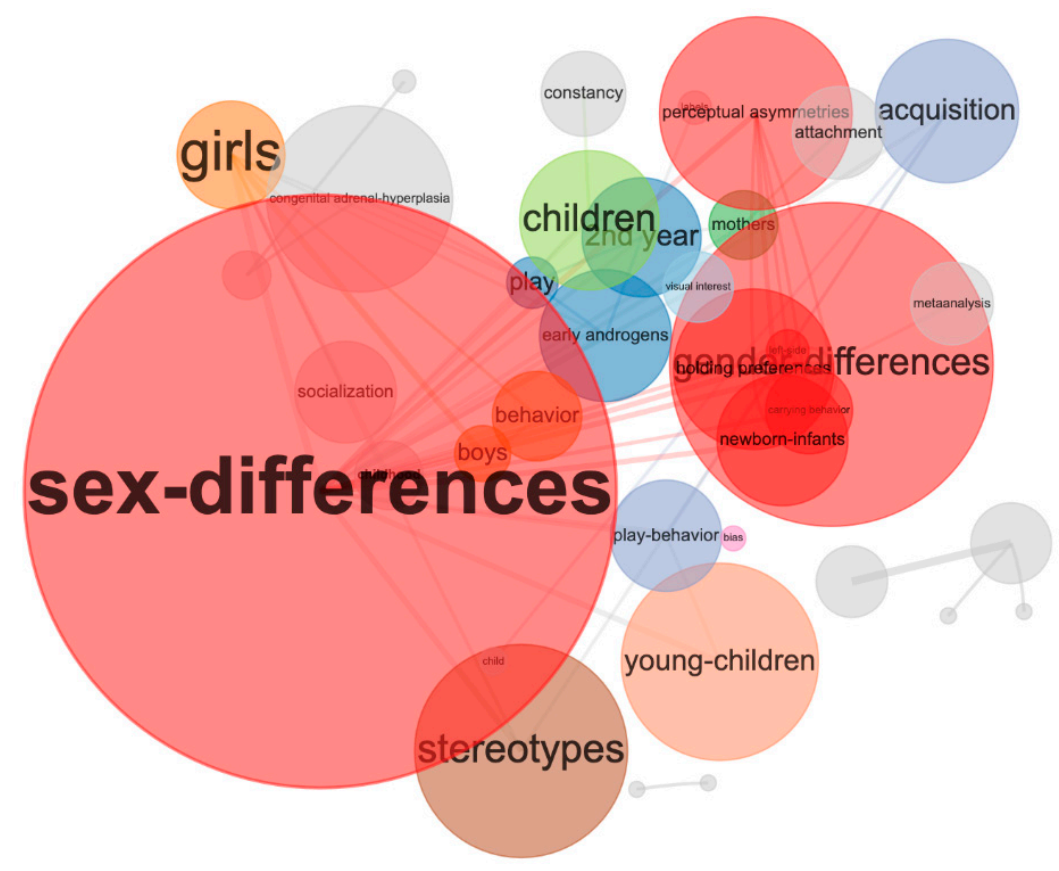

Figure 8. Co-occurrence network of concepts.

The collaboration network focuses on which countries show the greatest influence in the research of sexbots, and among them were the United Kingdom, the US, and Australia. We could not find any evidence that shows what is happening in Asian countries, and so we found this network to be a bit unrealistic.

To measure the source impact, we use the H-index as seen in Figure 9.

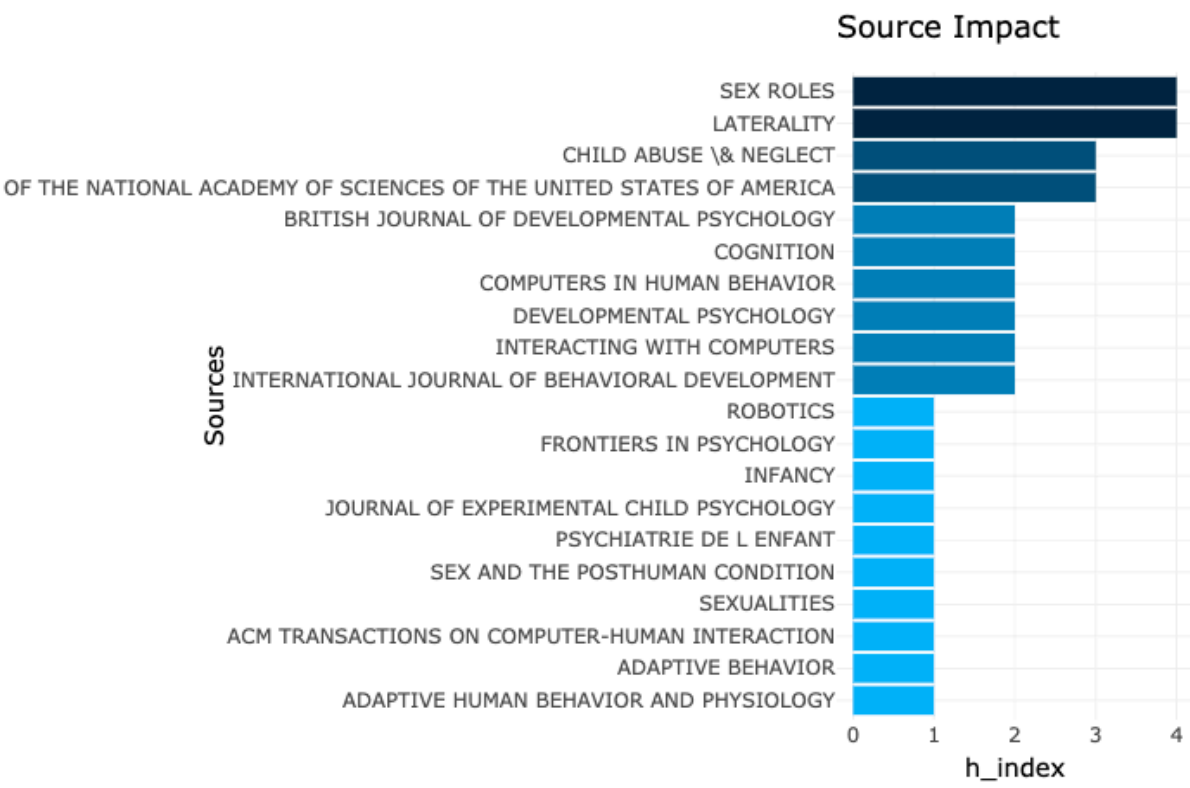

Figure 9. H-index of the sources used in the search.

We organized and synthesized the final selected studies into three different tables according to the research questions: RQ1 about design approaches (Table 1), RQ2 about interactions (Table 2), and RQ3 about gender and ethical issues (Table 3). When the paper emphasized one aspect over others, we decided to classify it in the option that predominated. In these cases, we chose interaction over the design in the first case and relationships over interactions in the second case. 
Table 1. Research question 1 (RQ1) about design approaches, type of study, and outcomes.

\begin{tabular}{|c|c|c|c|c|}
\hline Authors & Goals & Keywords & Type of Study & Main Outcomes \\
\hline $\begin{array}{l}\text { Green, MacDorman, } \\
\text { and Vasudevan } \\
(2008)[16]\end{array}$ & $\begin{array}{l}\text { To measure human } \\
\text { responses to varying } \\
\text { facial proportions in } \\
\text { people, androids, } \\
\text { mechanical-looking } \\
\text { robots, and two/three- } \\
\text { dimensional } \\
\text { characters }\end{array}$ & $\begin{array}{l}\text { Anthropomorphism, } \\
\text { attractiveness } \\
\text { perception, } \\
\text { facial acceptability, } \\
\text { interrater agreement, } \\
\text { uncanny valley }\end{array}$ & Survey study & $\begin{array}{l}\text { Significant correlations } \\
\text { were made between the } \\
\text { selection of best } \\
\text { proportions and ratings of } \\
\text { human likeness and } \\
\text { attractiveness. }\end{array}$ \\
\hline Norton et al. (1996) [17] & $\begin{array}{l}\text { To compare actual } \\
\text { proportions of adults' } \\
\text { body shape with dolls } \\
\text { (Barbie and Ken) }\end{array}$ & $\begin{array}{l}\text { Social psychology, } \\
\text { body shape }\end{array}$ & $\begin{array}{c}\text { Anthropometric } \\
\text { study }\end{array}$ & $\begin{array}{l}\text { Unrealistic body } \\
\text { proportions of Barbie and } \\
\text { Ken were compared to } \\
\text { real humans. }\end{array}$ \\
\hline $\begin{array}{l}\text { Szczuka et al. } \\
\text { (2017) [18] }\end{array}$ & $\begin{array}{c}\text { To compare men's } \\
\text { sexual attractiveness of } \\
\text { sex robots and women }\end{array}$ & $\begin{array}{l}\text { Sex robot, } \\
\text { personality traits, } \\
\text { attractiveness, } \\
\text { HRI }\end{array}$ & Survey study & $\begin{array}{l}\text { A negative attitude } \\
\text { towards robots is the main } \\
\text { user characteristic that } \\
\text { predicts the attractiveness } \\
\text { ratings of sex robots. }\end{array}$ \\
\hline Rousi (2018) [19] & $\begin{array}{l}\text { To problematize } \\
\text { human-robot love and } \\
\text { sex relationships }\end{array}$ & $\begin{array}{c}\text { Emotions, } \\
\text { robots, } \\
\text { sex, infidelity, } \\
\text { artificial intelligence }\end{array}$ & Review essay & $\begin{array}{l}\text { Human-robot love and sex } \\
\text { relationships are } \\
\text { problematized in the } \\
\text { eventuality of } \\
\text { artificial emotions. }\end{array}$ \\
\hline Hou and Ye (2019) [20] & $\begin{array}{l}\text { To test out sex } \\
\text { differences in } \\
\text { preferences for male } \\
\text { and female faces and } \\
\text { voices }\end{array}$ & $\begin{array}{c}\text { Sex differences } \\
\text { facial attractiveness, } \\
\text { vocal attractiveness, } \\
\text { mate preferences }\end{array}$ & Computerized test & $\begin{array}{l}\text { Men preferred voice } \\
\text { recordings and multimodal } \\
\text { stimuli of women. Women } \\
\text { did not show different } \\
\text { attractiveness ratings for } \\
\text { the voices of } \\
\text { men vs. women. }\end{array}$ \\
\hline
\end{tabular}

Table 2. Research question 2 (RQ2) about interactions, type of study, and outcomes.

\begin{tabular}{|c|c|c|c|c|}
\hline Authors & Goals & Keywords & Type of Study & Main Outcomes \\
\hline $\begin{array}{l}\text { Middle week } \\
\text { (2020) [21] }\end{array}$ & $\begin{array}{l}\text { To determine the } \\
\text { primary function of a } \\
\text { sex doll forum for its } \\
\text { users and perceptions } \\
\text { of sex robot technology }\end{array}$ & $\begin{array}{l}\text { Hegemonic masculinity, } \\
\text { homosociality, } \\
\text { human-robot } \\
\text { relationships, intimacy } \\
\text { sex dolls, sex robots }\end{array}$ & $\begin{array}{l}\text { Qualitative analysis } \\
\text { study of a major sex } \\
\text { doll forum }\end{array}$ & $\begin{array}{l}\text { Peer bonding was the } \\
\text { primary factor driving } \\
\text { member interaction. } \\
\text { Complex and dynamic } \\
\text { homosocial relations } \\
\text { characterized men's } \\
\text { online interaction. }\end{array}$ \\
\hline Döring et al. (2018) [22] & $\begin{array}{l}\text { To review the state of } \\
\text { technological } \\
\text { development and } \\
\text { research regarding sex } \\
\text { toys, sex dolls, and sex } \\
\text { robots marketed on } \\
\text { the Internet }\end{array}$ & $\begin{array}{l}\text { Sex toys, sex dolls, sex } \\
\text { robots, sexual products, } \\
\text { positive sexuality, } \\
\text { sexual pleasure }\end{array}$ & Review & $\begin{array}{l}\text { Positive impact was found } \\
\text { in terms of sex education, } \\
\text { sexual therapy, sexual } \\
\text { counseling, and sexual } \\
\text { well-being for interested } \\
\text { target groups (people with } \\
\text { disabilities, seniors). }\end{array}$ \\
\hline James (2017) [23] & $\begin{array}{l}\text { To analyze narratives } \\
\text { on the sex between } \\
\text { anabots and humans }\end{array}$ & Dystopia & Movie review & $\begin{array}{l}\text { The creation of sexual } \\
\text { desire as well as the nature } \\
\text { of objectification } \\
\text { was found. }\end{array}$ \\
\hline
\end{tabular}


Table 2. Cont.

\begin{tabular}{|c|c|c|c|c|}
\hline Authors & Goals & Keywords & Type of Study & Main Outcomes \\
\hline Burr-Miller (2013) [24] & $\begin{array}{l}\text { To study how men } \\
\text { have a relationship } \\
\text { with real dolls }\end{array}$ & $\begin{array}{l}\text { Heteronormativity, } \\
\text { gender performativity, } \\
\text { sexuality, iDollators, } \\
\text { Guys and Dolls }\end{array}$ & Essay & $\begin{array}{l}\text { Men's violations of the } \\
\text { charmed circle are framed } \\
\text { in the documentary } \\
\text { due to unrequited } \\
\text { heterosexual desires. }\end{array}$ \\
\hline $\begin{array}{l}\text { Gomes and Wu } \\
\text { (2018) [25] }\end{array}$ & $\begin{array}{l}\text { Design a sex toy for } \\
\text { people with disabilities } \\
\text { and people in } \\
\text { long-distance } \\
\text { relationships }\end{array}$ & $\begin{array}{l}\text { Brain-computer } \\
\text { interface, sex toys, } \\
\text { long-distance } \\
\text { relationships }\end{array}$ & Product design & $\begin{array}{l}\text { The Neurodildo, a sex toy } \\
\text { remotely controlled by } \\
\text { brain waves, which is } \\
\text { pressure sensitive and has } \\
\text { electrical stimulation } \\
\text { (e-stim) feedback, } \\
\text { was presented. }\end{array}$ \\
\hline $\begin{array}{l}\text { McArthur and Twist } \\
\text { (2017) [26] }\end{array}$ & $\begin{array}{l}\text { To create a design } \\
\text { framework for } \\
\text { digisexuality }\end{array}$ & $\begin{array}{l}\text { Digisexuality, sexbot, } \\
\text { robot, virtual reality, } \\
\text { sex therapy }\end{array}$ & Essay & $\begin{array}{l}\text { A framework for } \\
\text { understanding the nature } \\
\text { of digisexuality and how to } \\
\text { approach it is imperative. }\end{array}$ \\
\hline Tay et al. (2016) [27] & $\begin{array}{l}\text { To study humor as an } \\
\text { element of interaction } \\
\text { between robots and } \\
\text { humans }\end{array}$ & $\begin{array}{l}\text { Social robots, humor, } \\
\text { social attraction, facial } \\
\text { expression }\end{array}$ & Experimental study & $\begin{array}{l}\text { Humor can be an effective } \\
\text { way to enrich interactions } \\
\text { between humans and } \\
\text { robots, but the acceptable } \\
\text { types of humor should be } \\
\text { carefully selected. }\end{array}$ \\
\hline $\begin{array}{l}\text { Harper and Lievesley } \\
\text { (2020) [28] }\end{array}$ & $\begin{array}{l}\text { To examine the veracity } \\
\text { of the existing } \\
\text { psychological, } \\
\text { sexological, and legal } \\
\text { literature concerning } \\
\text { doll ownership }\end{array}$ & $\begin{array}{l}\text { Sex dolls, sexuality, sex } \\
\text { robots, sex offending, } \\
\text { sexual abuse } \\
\text { prevention }\end{array}$ & Literature review & $\begin{array}{l}\text { There is a lack of analyses } \\
\text { of the psychological } \\
\text { characteristics or behaviors } \\
\text { of sex doll owners. No } \\
\text { standardized measure of } \\
\text { attitudes towards sex dolls } \\
\text { and robots exists. It was } \\
\text { found that } 70 \% \text { of owners } \\
\text { used the robot as a sexual } \\
\text { companion, while } 30 \% \\
\text { used it for social compan- } \\
\text { ionship/friendship. }\end{array}$ \\
\hline $\begin{array}{l}\text { Eichenberg, Khamis, } \\
\text { and Hübner (2019) [29] }\end{array}$ & $\begin{array}{l}\text { To measure attitudes of } \\
\text { sex therapists and } \\
\text { physicians toward the } \\
\text { therapeutic uses of } \\
\text { sex robots }\end{array}$ & $\begin{array}{l}\text { Robotics, sexual } \\
\text { health, therapy }\end{array}$ & $\begin{array}{l}\text { Quantitative online } \\
\text { survey and a } \\
\text { qualitative } \\
\text { interview study }\end{array}$ & $\begin{array}{l}\text { Therapists and physicians } \\
\text { could recommend sex } \\
\text { robots in therapy. } \\
\text { Heterogeneous attitudes } \\
\text { were found. Psychologists } \\
\text { were more critical toward } \\
\text { the therapeutic use of sex } \\
\text { robots. Patients with social } \\
\text { anxiety can benefit from } \\
\text { using sex robots. }\end{array}$ \\
\hline Su et al. (2019) [30] & $\begin{array}{l}\text { To examine how people } \\
\text { in the future might } \\
\text { relate to robots and } \\
\text { similar technologies } \\
\text { and agents }\end{array}$ & $\begin{array}{l}\text { Sexuality, intimacy, } \\
\text { wellness, care, } \\
\text { embodiment, robots, } \\
\text { online forums }\end{array}$ & $\begin{array}{l}\text { Qualitative analysis } \\
\text { of forums }\end{array}$ & $\begin{array}{l}\text { Sex dolls are used for more } \\
\text { than just sex. Fiction and } \\
\text { intimate fantasies are more } \\
\text { persuasive if they are } \\
\text { customizable } \\
\text { (sexual robots). }\end{array}$ \\
\hline
\end{tabular}


Table 2. Cont.

\begin{tabular}{|c|c|c|c|c|}
\hline Authors & Goals & Keywords & Type of Study & Main Outcomes \\
\hline $\begin{array}{l}\text { Langcaster-James and } \\
\text { Bentley (2018) [31] }\end{array}$ & $\begin{array}{l}\text { To explore motivations } \\
\text { and experiences of } \\
\text { those who purchase } \\
\text { and use sex dolls }\end{array}$ & $\begin{array}{l}\text { Sex doll, sex robots, } \\
\text { companionship, } \\
\text { posthuman kinship, } \\
\text { allodoll }\end{array}$ & Mixed methods & $\begin{array}{l}\text { Some doll owners } \\
\text { appeared to establish a rich } \\
\text { fantasy life, generating } \\
\text { characters and } \\
\text { personalities for their dolls } \\
\text { and considering what they } \\
\text { might think or say. }\end{array}$ \\
\hline $\begin{array}{l}\text { Döring and Poeschl } \\
\text { (2019) [32] }\end{array}$ & $\begin{array}{l}\text { To analyze media } \\
\text { representations of } \\
\text { intimate human-robot } \\
\text { relationships }\end{array}$ & $\begin{array}{l}\text { Human-robot } \\
\text { relationships, sex } \\
\text { robots, media } \\
\text { representation, sexual } \\
\text { script theory, gender } \\
\text { roles, media content } \\
\text { analysis }\end{array}$ & Content analysis & $\begin{array}{l}\text { Media often portray the } \\
\text { involved robot partner as a } \\
\text { humanoid female sex robot. } \\
\text { Nonfictional media } \\
\text { describe intimate } \\
\text { human-robot relationships } \\
\text { more often in sexual terms; } \\
\text { fictional media focus more } \\
\text { on emotional aspects. }\end{array}$ \\
\hline
\end{tabular}

Table 3. Research question 3 (RQ3) about gender and ethics, type of study, and outcomes.

\begin{tabular}{|c|c|c|c|c|}
\hline Authors & Goals & Keywords & Type of Study & Main Outcomes \\
\hline Whitby (2008) [33] & $\begin{array}{l}\text { To make ethical } \\
\text { recommendations for } \\
\text { designers }\end{array}$ & $\begin{array}{c}\text { Robot ethics, abusive } \\
\text { interaction, ethical } \\
\text { design }\end{array}$ & Essay & $\begin{array}{l}\text { Reflections on the } \\
\text { sexual-affective effects of } \\
\text { uses of sex robots were } \\
\text { found. Robots that behave } \\
\text { similarly as humans do are } \\
\text { precisely the sort of robots } \\
\text { most likely to be abused. }\end{array}$ \\
\hline Chatterjee (2020) [34] & $\begin{array}{l}\text { To explore the debate } \\
\text { on whether child sex } \\
\text { dolls and robots could } \\
\text { and should be caught } \\
\text { by the child protection } \\
\text { framework }\end{array}$ & $\begin{array}{l}\text { Child sex dolls, child } \\
\text { sex robots, } \\
\text { criminalization }\end{array}$ & Essay & $\begin{array}{l}\text { New crimes under the } \\
\text { Sexual Offences Act } 2003 \\
\text { (SOA) were proposed. }\end{array}$ \\
\hline Brown et al. (2019) [35] & $\begin{array}{l}\text { To analyze the risk and } \\
\text { possible negative } \\
\text { impacts of the use of } \\
\text { child sex dolls }\end{array}$ & $\begin{array}{l}\text { Child sex dolls, crime, } \\
\text { criminal justice }\end{array}$ & Review & $\begin{array}{l}\text { Interaction with child sex } \\
\text { dolls could increase the } \\
\text { likelihood of child sexual } \\
\text { abuse and normalize the } \\
\text { behavior in the } \\
\text { abuser's mind. }\end{array}$ \\
\hline Ángel (2016) [36] & $\begin{array}{l}\text { To explore the risks of } \\
\text { the hybridization } \\
\text { process and } \\
\text { simulations }\end{array}$ & $\begin{array}{l}\text { Feminism, gender } \\
\text { violence, media, } \\
\text { biotechnology, } \\
\text { simulations }\end{array}$ & Analysis & $\begin{array}{l}\text { It is essential to incorporate } \\
\text { the gender perspective into } \\
\text { the technological impact. }\end{array}$ \\
\hline Yulianto (2019) [37] & $\begin{array}{l}\text { To study the ethical } \\
\text { issues and legal } \\
\text { regulations of } \\
\text { sex robots }\end{array}$ & $\begin{array}{l}\text { Transhumanism, } \\
\text { human enhancement, } \\
\text { posthuman }\end{array}$ & Essay & $\begin{array}{l}\text { Human-nature ethics, such } \\
\text { as deontological or } \\
\text { consequentialist ethics, } \\
\text { are not suitable for } \\
\text { machine morality. }\end{array}$ \\
\hline
\end{tabular}


Table 3. Cont.

\begin{tabular}{|c|c|c|c|c|}
\hline Authors & Goals & Keywords & Type of Study & Main Outcomes \\
\hline Connor (2015) [38] & $\begin{array}{l}\text { To explore the } \\
\text { objectification of } \\
\text { women through } \\
\text { sex dolls }\end{array}$ & $\begin{array}{l}\text { Dolls, women, } \\
\text { objectification }\end{array}$ & Essay & $\begin{array}{l}\text { The doll brings together } \\
\text { the histories of sexual } \\
\text { desire and religion. }\end{array}$ \\
\hline Mackenzie (2018) [5] & $\begin{array}{l}\text { To debate on sex robots } \\
\text { and their social } \\
\text { interaction } \\
\text { with humans }\end{array}$ & $\begin{array}{l}\text { Sexbot, roboethics, } \\
\text { robot law, and right }\end{array}$ & Review essay & $\begin{array}{l}\text { The ethical limits and legal } \\
\text { implications of } \\
\text { customizable human-like } \\
\text { robots must be } \\
\text { addressed urgently. }\end{array}$ \\
\hline $\begin{array}{c}\text { Frank and Nyholm } \\
\text { (2017) [39] }\end{array}$ & $\begin{array}{l}\text { To explores the } \\
\text { designing of } \\
\text { humanoid robots }\end{array}$ & $\begin{array}{l}\text { Sex robots, rape, } \\
\text { artificial intelligence, } \\
\text { consent, legal } \\
\text { community }\end{array}$ & Review, discussion & $\begin{array}{l}\text { The discussion on whether } \\
\text { it is conceivable, possible, } \\
\text { and desirable that } \\
\text { humanoid robots should } \\
\text { be designed such that they } \\
\text { can consent to sex } \\
\text { was explored. }\end{array}$ \\
\hline Ess (2017) [40] & $\begin{array}{l}\text { To explore love and sex } \\
\text { between robots } \\
\text { and humans }\end{array}$ & $\begin{array}{l}\text { Social robot, sexuality, } \\
\text { love, and sex }\end{array}$ & $\begin{array}{c}\text { Philosophical } \\
\text { dissertation, essay }\end{array}$ & $\begin{array}{l}\text { Social robots lack } \\
\text { substantial autonomy, } \\
\text { genuine emotion, and } \\
\text { self-awareness, thereby } \\
\text { falling short of what is } \\
\text { required by the complete } \\
\text { experience of sex to } \\
\text { establish experiences of } \\
\text { mutual desire, love, } \\
\text { and respect. }\end{array}$ \\
\hline $\begin{array}{l}\text { Brahnam and De } \\
\text { Angeli (2012) [41] }\end{array}$ & $\begin{array}{l}\text { To explore gender } \\
\text { affordances of } \\
\text { conversational agents }\end{array}$ & $\begin{array}{c}\text { Sexuality and HCI, } \\
\text { gender, agent abuse, } \\
\text { embodied } \\
\text { conversational agents, } \\
\text { sex stereotypes }\end{array}$ & Test & $\begin{array}{l}\text { The application of gender } \\
\text { stereotypes in the } \\
\text { interaction with chatterbots } \\
\text { often leads to attitudes } \\
\text { more dismissive toward } \\
\text { women than men. }\end{array}$ \\
\hline Danaher (2019) [42] & $\begin{array}{l}\text { To debate on regulatory } \\
\text { issues about child } \\
\text { sexual robots }\end{array}$ & $\begin{array}{l}\text { Legal regulation, child } \\
\text { sexual robots, } \\
\text { experimentation, } \\
\text { restrictions }\end{array}$ & Essay & $\begin{array}{l}\text { The restrictive approach to } \\
\text { regulation is the } \\
\text { wisest choice. }\end{array}$ \\
\hline $\begin{array}{l}\text { Headleand, Teahan, } \\
\text { and Cenydd (2020) [43] }\end{array}$ & $\begin{array}{l}\text { To explore ethical } \\
\text { safeguards into sexual } \\
\text { robots as well as } \\
\text { artificial morality in } \\
\text { robots/agents }\end{array}$ & $\begin{array}{c}\text { Sexbots, artificial } \\
\text { sexuality, artificial } \\
\text { ethical agent, moral } \\
\text { agency }\end{array}$ & Literature review & $\begin{array}{l}\text { Commercializing sex with } \\
\text { robots could reinforce } \\
\text { existing gender inequalities } \\
\text { and sexual objectification. } \\
\text { No consensus on what is } \\
\text { considered moral between } \\
\text { cultures exists. Review also } \\
\text { covers ethical boundaries } \\
\text { and contributes to } \\
\text { moral philosophy. }\end{array}$ \\
\hline
\end{tabular}


Table 3. Cont.

\begin{tabular}{|c|c|c|c|c|}
\hline Authors & Goals & Keywords & Type of Study & Main Outcomes \\
\hline $\begin{array}{c}\text { Fiske, Henningsen, and } \\
\text { Buyx (2019) [44] }\end{array}$ & $\begin{array}{l}\text { To explore ethical and } \\
\text { social implications of } \\
\text { translating embodied } \\
\text { AI applications into } \\
\text { mental health care }\end{array}$ & $\begin{array}{l}\text { Artificial intelligence, } \\
\text { robotics, ethics, } \\
\text { psychiatry, psychology, } \\
\text { psychotherapy, } \\
\text { medicine }\end{array}$ & Literature review & $\begin{array}{l}\text { New modes of treatment } \\
\text { and opportunities were } \\
\text { presented. A lack of } \\
\text { guidance on the } \\
\text { development of AI } \\
\text { applications was found. } \\
\text { Gaps in ethical and } \\
\text { regulatory frameworks } \\
\text { exists. Harm prevention } \\
\text { and data ethics issues } \\
\text { were covered. }\end{array}$ \\
\hline $\begin{array}{l}\text { Nordmo et al. } \\
\text { (2020) [45] }\end{array}$ & $\begin{array}{l}\text { To explore relationships } \\
\text { and gender differences } \\
\text { about platonic love } \\
\text { robot or a sex robot }\end{array}$ & $\begin{array}{l}\text { Robot, relationships, } \\
\text { jealousy, gender } \\
\text { differences, } \\
\text { companionship, sex, } \\
\text { artificial intelligence }\end{array}$ & $\begin{array}{l}\text { Online study } \\
\text { (vignette about a } \\
\text { sexual robot) }\end{array}$ & $\begin{array}{c}\text { Females have less positive } \\
\text { views of robots, and } \\
\text { especially of sex robots, } \\
\text { compared to men. People } \\
\text { project their feelings about } \\
\text { robots onto their partner. }\end{array}$ \\
\hline
\end{tabular}

\section{Discussion}

Design, interaction, and ethics and gender approaches are the three issues we chose to evaluate the literature with. The questions previously mentioned are answered with the literature review in this section.

\subsection{RQ1: How Are Sexbots Designed?}

In a previous work [46], we found that there are different approaches to sex robot design [7,47-56], of which we can highlight two [48], i.e., the functional ones, which are not based on cognitive functions in designing social robots, and the biological ones, which are based on cognitive models and natural sciences. Furthermore, we can observe other methods coming from biomimetic robotics [47], social robotics [49], and biohybrid neuroprosthetic systems related to biomedical engineering and neuroscience [52,53]. Based on this systematic review, we see that there has been a greater interest in the opinion of human users within the past ten years, more specifically, in men, about how a sex robot should be designed. We hardly found any articles on designing the functionality or the possible biological inspirations that a sex robot's design may have. Moreover, studies on comparisons between sexbots/sex dolls and human beings deduce exactly which qualities are the most attractive [17,36]. Again, more studies have been done on sex dolls and sex robots for male users [16]. We wonder whether these studies will be decisive when designing sexbots.

Considering the results of this systematic review, we can note that there are sex differences in male and female faces and voices [20]. Males prefer more female voices and stimulus. Some sex toys might also help people with disabilities and people in long-distance relationships (LDR) [25]. In addition, there are guidelines for helping individuals and relational systems make informed choices regarding the participation in technology-based activities [26].

\subsection{RQ2. How Do Sexbots Interact with Humans?}

A sexbot is a social robot $[24,54]$ that can interact with humans through vision (through cameras), voice (through microphones and speakers), touch (through capacitive sensors or contact microphones), cognition, and emotion (through cognitive modeling and behavioral responses, perceiving, and expressing emotions) [54].

For example, Samantha [55] is a sexbot who has sensors on her hips, shoulders, vagina, and mouth, and can respond to touch. In addition, it has a sexy or familiar mode, 
programmed with artificial intelligence, and users decide the context they can interact with it in one way or another.

Based on our systematic review, the affective aspect can be essential. For instance, in the movie Guys and Dolls [24], we find a protagonist in love and married to his robot. Other mechanisms are put in place in the relationships between humans and sex robots apart from sexual ones, as shown in the documentary, such as relationships of control. One male protagonist, who collects different sex robots in his garage, feels he will never control a real woman in the same way as controlling a robot. Another type of relationship is based on the kind being a hobby, that is, as long as an interesting woman does not appear, the user continues to be with a sexbot.

The relationships between human beings (males in this case) and their sex robots also can be very complex, as an analysis in a sex forum demonstrated [21]. The most cited reason was "doll maintenance" for interaction among peers. The study found that peer bonding was the primary factor driving member interaction-a result consistent with studies of pornography forum fan pages in which collectivity and peer approval are paramount in online sexual cultures. Movies such as 2040 [23] fantasizes the sexual relations between human beings and what they called "anabots", particularly in the scenes that dramatize sex between anabots and humans, allowing the film to comment on the role that technology has.

There is a lack of empirical analyses of doll ownership psychological characteristics or behavioral implications, and no standardized measure of the attitudes towards sex dolls and robots and their owners exists [28]. Moreover, sex therapists and physicians have different opinions about the therapeutic benefits of sex robots [29], although the attitudes toward sex robots as a therapeutic tool were very heterogeneous, depending on gender, age, and occupational differences. Psychologists (in contrast to physicians) were more critical toward the therapeutic use of sex robots. The most frequent use was seen in patients with social anxiety that prevents a sexual life.

One study showed that sex dolls are used for more than just sex [30]. Some owners use dolls to create a sort of embodied intimate fiction. Intimate fantasies are persuasive if they are customizable, which is a characteristic that can be considered in the design of sex robots. In this sense, there is a high prevalence of nonsexual, posthuman companionship dynamics between dolls and their owners [31]. Media representations of intimate humanrobot relationships were studied by [32], who found that such representations portray the involved human partner as a disadvantaged man in interpersonal relationships.

Some authors tried to understand the implications of introducing emotions into robotic machinery [19]. In the future, robots can experience emotionally and sexually satisfying partnerships; perhaps the emphasis should be once again placed on humans. The relationship between machines and humans has been studied under the concept of good sex and complete sex, and in this case, their mutual respect is needed [40]. Humor can be another component in the interaction between humans and robots [27]. However, acceptable types of humor should be carefully selected.

\subsection{RQ3: What Gender and Ethical Issues Are Related to the Design and USE of Sexbots?}

We have organized the discussion on this question in two subsections: (a) gender approaches and (b) ethics approaches. Following we present the main related findings.

\section{(a) Gender approaches}

In our review, almost no study was found regarding women using male sex robots except in [29]. In this way, both the design and the interaction are biased because there is a male hegemony seen. A female perspective is needed to guarantee gender equity.

Some authors [45] focused on relationships, concretely on jealousy. As we saw in the interactions between humans and robots, as the manufacture of sexbots is perfected, the relationships between humans and these robots will become more complex. Therefore, when the sexbot does not have a single function, and a romantic or emotional relationship appears, gender differences appear between a platonic love robot and a sex robot, in that 
the robot becomes a partner. In an online study (i.e., a vignette about a sexual robot), females have less favorable views of robots, especially sex robots, compared to men. This means that women place more importance on the fact that their partner got a sex robot rather than a platonic love robot, and females are expected to feel more jealous. Females who read about sex robots reported significantly elevated levels of jealousy, less favorable attitudes, a greater level of dislike, and a greater level of a predicted partner's dislike. The fear of the unknown, or the partner's insecurities, is projected onto the partner, causing jealousy to appear.

Media representations of intimate human-robot relationships are also biased. In this sense, some authors [32] explained how media representations of intimate human-robot relationships portray the involved human partner as a disadvantaged man in interpersonal relationships. Therefore, media often portray the involved robot partner as a female humanoid sex robot. Nonfictional media describe intimate human-robot relationships more often in sexual terms because a product or service is offered; fictional media focus more on emotional aspects because this involves a fantasy. Media representations of intimate human-robot relationships reveal stereotypical gender roles, heteronormativity, and a focus on sexual versus emotional intimacy. In all its variants, such as comics, series, books, or movies, science fiction provides habitually hypersexual heroines.

Articles in the past decade focus more on concrete interactions. Some researchers [41] explored gender affordances of conversational agents. Their examination takes a holistic approach in analyzing the application of gender stereotypes to nine chatterbots: six embodied (three male and three female), two disembodied (male and female), and a robot embodiment. Feeling accompanied is not only achieved by physically having an object or someone close. Affectivity again appears as a recurring theme in this field. For this reason, a conversation thought of as an affective interaction is an element that must be taken into consideration. The authors tested the persistence of gender stereotypes in selecting conversation topics (the referential aspect of conversation) and the elicitation of disinhibition and verbal abuse (the relational aspect of conversation). Two main hypotheses were formed, with the first one on a gender-related conversational topic hypothesis. In other words, conversations with female-presenting agents will revolve more around social relations and physical appearance than conversations with male-embodied agents. These can be seen in some everyday examples, such as the conversational agents around us; they usually have a female voice and a woman's name, such as Alexa, Cortana, or Siri. For the second hypothesis, i.e., the so-called disinhibition hypothesis, the authors expected that conversations with male-presenting agents would more frequently focus on activities, compared to conversations with female-presenting agents. As females are often perceived to have less status and are usually objects of sexual attention, female agents are expected to be the recipients of more disinhibited behavior. In particular, it is expected that female-presenting agents would be the recipients of more sex talk and verbally abusive behaviors than malepresenting agents. It should be noted that this is a risky hypothesis if the sample of users is not biased concerning sexual orientation. They concluded that gender stereotypes tend to affect interaction more at the relational (style) level than at the referential (content) level of conversation. Usually, people attribute negative stereotypes to female-presenting chatterbots more often than male-presenting chatterbots. Female-presenting chatterbots are more often the objects of implicit and explicit sexual attention and swear words. They claimed a more informed analysis of user interactions that considers the full range of user interactions.

Moreover, we consider other groups with different sexual orientations because users follow stereotypical gender patterns when conversing with chatbots presented as either male or female. These gender patterns tended mainly to affect the relational aspect rather than the referential aspect of the conversation. This bias is seen from the investigation. The application of gender stereotypes in the interaction with chatbots often leads to more dismissive attitudes toward women than men. 


\section{(b) Ethics approaches}

Fortunately, various laws to protect the most disadvantaged individuals, such as children, have appeared in this past decade. Governments should try to protect all these cases that appear, including possibilities that we could not yet imagine.

New crimes under the Sexual Offences Act 2003 (SOA) that address the creation, distribution, and possession of child sex dolls and robots where a real child is involved in their creation has been proposed by [34]. Where sex dolls and robots are fantasy creations, it is argued that different considerations arise, and it is difficult to justify the same range of restrictions. Accordingly, separate SOA offenses are suggested, with exceptions made for self-made artifacts intended solely for private use. In this way, the law adapts to the origin of the sexbot, its conception, and the original idea, separating the fantasy from the physical world's replica.

One point to always keep in mind is that there is a business chain involved, i.e., the distributor, the seller, the supplier, and the consumer. In this line, we seek to answer questions about what is provided, who consume it, and what they do with it since it can be for their own consumption or redistribution. For laws to be efficient, they must consider all these aspects.

The debate about "seeing the glass half full or half empty" is a common denominator in all these challenges that we must face as a society. Are these products and services an opportunity to help people with sexual or relationship problems [22]? Alternatively, should they be prohibited because they are something that is against nature? An essay about the legal regulations about child sexual robots [42], highlighted the "dark field" problem where the restrictive approach to regulation is the wisest choice because when there are children in the way, they must be protected at all costs so as to not be attacked under any circumstances, which is a point also addressed in [35]. However, all individuals must be protected. In the ethical safeguards into sexual robots, [43] conducted a literature review about the artificial morality in robots/agents because commercializing sex with robots could reinforce existing gender inequalities and sexual objectification. Some issues are considered as the "no consensus", which depends on the culture, and this was examined by [39], who explored whether it is conceivable, possible, and desirable that humanoid robots should be designed such that they are capable of consenting to sex. They considered the reasons for giving both "no" and "yes" answers to three questions by examining the concept of consent in general, as well as critiques of its adequacy in the domain of sexual ethics, the relationship between consent and free will, and the relationship between consent and consciousness.

Also, the frame problem where there is an evaluation of the consequences of the acts, was faced by [43], considering that this evaluation involves ethical behavior. This ethical behavior is the object of the evaluation. Another aspect is the ethical boundaries that can be approached by simulating ethical dilemmas. As a particular objective, it was proposed to have contributions to the moral philosophy, assuming that perhaps some traditional theories should be challenged to codify ethics.

On the positive side, in their ethical and social implications of translating embodied AI applications into mental health care across the fields of psychiatry, psychology, and psychotherapy, [44] conducted a literature review of new modes of treatment, opportunities to engage hard-to-reach populations, better patient responses, and freeing up time for physicians. A lack of guidance on the development of AI applications, their clinical integration, and health professionals, as well as missing points in ethical and regulatory frameworks, are challenging. From a realistic vision, there is a potential for misuse, including using the technologies to replace established services, thereby potentially exacerbating existing health inequalities. Values such as harm prevention and data ethics issues were also highlighted.

The point of view on sex robots will need to be clarified [33] and challenged as technology advances towards sex robots with "awareness". While it may be possible to name a multitude of studies on creating artificial consciousness, it appears that to date, no one has yet formulated 
an unquestionable definition of consciousness since the existing definitions are speculations and models of how consciousness is believed to operate. The nature of consciousness has been and continues to be studied, but there is no unified explanation on how it can be generated. The debate about whether it can be generated in the distant future is also open for debate. However, in the past decade, articles such as [5] speculating the ethical limits and legal implications of customizable human-like robots, which must be addressed urgently, propose a duty that humans have as creators to safeguard the interests and minimize the suffering of created sentient beings before technological advances preempt this possibility. How we design and customize sexbots and how we treat them matters for us, as well as the future of human/human, human/sexbot, and sexbot/sexbot intimate relations for the sake of achieving harmony between humans and sexbots. Moreover, these questions are part of a broader debate on what ethical duties humans as creators owe the sentient entities they create. Codes of ethical design and flexible regulation that build upon and expand existing ethical codes governing intelligent and autonomous systems to balance and safeguard human interests and the created sentient, self-aware entities must be put in place urgently before technological advances preempt them.

Philosophical essays about the nature of sex robots or their behavior are analyzed in relation to the concepts of life and death [38]. There is a struggle between these two concepts when an inanimate subject comes to play. A revision of traditional philosophical theories supports this relationship.

The distance between a robot and a person causes some authors to find ethics of human nature, such as deontological or consequential ethics, as not adequate to be applied in a hypothetical moral of the machine [37].

\section{Conclusions}

Although society has perceived robots differently in the past, these differences are minimal today, depending on their culture or religion. This paper analyzed the state-of-theart concerning sex robots, with a focus on the design, interaction, and gender and ethics approach in the last 40 years, by doing an extensive review in Scopus and WoS. As the principal outcomes of this systematic study, we noted the following:

- $\quad$ Some laws are in place with the aim to protect vulnerable individuals, even children.

- There is a real concern about how the interactions between sexbots and human beings will become. Positive and negative consequences appeared in the literature.

- $\quad$ The sexbot design process appears to be oriented by the opinions of human users.

- $\quad$ Design dark patterns must be avoided in designing sexual robots.

- $\quad$ Technology seems to be mature enough to claim a user-centered design.

- Male bias is present in the design, interaction, and even ethics.

- $\quad$ Positive therapeutic uses of sexual robots were found in the literature.

- Sexual robots and dolls are used more than just sex (as companions, friendship, fantasy, etc.).

- $\quad$ Sexual robots are stereotyped, mainly based on female figures (pornography).

- Regarding data related to pedophiles and child-robots, there is currently no evidence of a relationship between the two [44]. However, restrictive regulations on child sex robots are recommended instead of open to experimentation.

Interaction with robots is becoming more realistic, which can affect human perception. Therefore, issues such as ethics and gender must be considered in the design of sexual robots. IEEE initiatives consider ethics in the creation of technology [56], as well as other initiatives [56], which can assist in the design of sexual robots. In addition, new philosophical paradigms appear when we talk about sentient robots. Therefore, both designers and users must be aware of the consequences of the use of sexbots.

Author Contributions: Conceptualization, C.S.G.-G., R.M.G.-I. and P.P.-R.; methodology, C.S.G.-G., R.M.G.-I. and P.P.-R.; formal analysis, C.S.G.-G., R.M.G.-I. and P.P.-R.; investigation, C.S.G.-G., R.M.G.-I. and P.P.-R.; resources, C.S.G.-G. and R.M.G.-I.; data curation, C.S.G.-G., R.M.G.-I. and 
P.P.-R.; writing — original draft preparation, C.S.G.-G., R.M.G.-I. and P.P.-R. All authors have read and agreed to the published version of the manuscript.

Funding: This research received no external funding.

Institutional Review Board Statement: Not applicable.

Informed Consent Statement: Not applicable.

Data Availability Statement: No new data were created or analyzed in this study. Data sharing is not applicable to this article.

Conflicts of Interest: The authors declare no conflict of interest.

\section{References}

1. Goodrich, M.A.; Schultz, A.C. Human-robot interaction: A survey. Found. Trends ${ }^{\circledR}$ Human Comput. Interact. 2008, 1, $203-275$. [CrossRef]

2. Shen, F. Sex Robots Are Here, But Laws Aren't Keeping up with the Ethical and Privacy Issues They Raise. 2019. Available online: https: / / theconversation.com/sex-robots-are-here-but-laws-arent-keeping-up-with-the-ethical-and-privacy-issues-theyraise-109852 (accessed on 29 September 2020).

3. Boot, G. Lifelike and Cheap Sex Robots Made with 3D Printers Will Fuel Surge in Addiction. The Sun 2018. Available online: https: / / www.thesun.co.uk/tech/7998023/lifelike-and-cheap-sex-robots-made-with-3d-printers-will-fuel-surge-in-addiction/ (accessed on 29 September 2020).

4. Bame, Y. 1 in 4 Men Would Consider Having Sex with a Robot. 2017. Available online: https://today.yougov.com/topics/ lifestyle/articles-reports/2017/10/02/1-4-men-would-consider-having-sex-robot (accessed on 29 September 2020).

5. Mackenzie, R. Sexbots: Customizing them to suit us versus an ethical duty to created sentient beings to minimize suffering. Robotics 2018, 7, 70. [CrossRef]

6. Bhaumik, A. From AI to Robotics: Mobile, Social, and Sentient Robots; CRC Press: Boca Raton, FL, USA, 2018.

7. Levy, D. Love and Sex with Robots: The Evolution of Human-Robot Relationships; Harper Perennial: New York, NY, USA, 2009.

8. McClelland, R.T. Confronting Emerging New Technology: The Case of the Sexbots. J. Mind Behav. 2017, 38, 247-270.

9. Cheok, A.D.; Levy, D.; Karunanayaka, K. Lovotics: Love and sex with robots. In Emotion in Games; Springer: Cham, Switzerland, 2016; pp. 303-328.

10. Taylor, J. Sex Robot with a Personality Unveiled. Roxxxy. Metro. 2010. Available online: https://metro.co.uk/2010/01/11 / worlds-first-sex-robot-with-a-personality-unveiled-as-roxxxy-23255/ (accessed on 29 September 2020).

11. Harmony Realdoll. Available online: https:/ / realbotix.com/ (accessed on 29 September 2020).

12. Meet Henry, the Robot with Superhuman Sexual Prowess, Hoping to Titillate Women. 2018. Available online: https://www.rt. $\mathrm{com} /$ news / 427246-male-sexbot-women-companionship/ (accessed on 29 September 2020).

13. Hintze, A. Understanding the Four Types of AI, from Reactive Robots to Self-Aware Beings. 2016. Available online: https: / theconversation.com/understanding-the-four-types-of-ai-from-reactive-robots-to-self-aware-beings-67616 (accessed on 29 September 2020).

14. Cheok, A.D.; Zhang, E.Y. Sex and a History of Sex Technologies. In Human-Robot Intimate Relationships; Springer: Cham, Switzerland, 2019; pp. 23-32.

15. Moher, D.; Liberati, A.; Tetzlaff, J.; Altman, D.G.; The PRISMA Group. Preferred Reporting Items for Systematic Reviews and Meta-Analyses: The PRISMA Statement. PLOS Med. 2009, 6, e1000097. [CrossRef] [PubMed]

16. Green, R.D.; MacDorman, K.F.; Ho, C.C.; Vasudevan, S. Sensitivity to the proportions of faces that vary in human likeness. Comput. Hum. Behav. 2008, 24, 2456-2474. [CrossRef]

17. Norton, K.I. Ken and Barbie at life size. Sex Roles 1996, 34, 287-294. [CrossRef]

18. Szczuka, J.M.; Krämer, N.C. Not Only the Lonely-How Men Explicitly and Implicitly Evaluate the Attractiveness of Sex Robots in Comparison to the Attractiveness of Women, and Personal Characteristics Influencing This Evaluation. Multimodal Technol. Interact. 2017, 1, 3. [CrossRef]

19. Rousi, R. Me, My Bot and His Other (Robot) Woman? Keeping Your Robot Satisfied in the Age of Artificial Emotion. Robotics 2018, 7, 44. [CrossRef]

20. Hou, J.; Ye, Z. Sex Differences in Facial and Vocal Attractiveness Among College Students in China. Front. Psychol. 2019, 10, 1166. [CrossRef]

21. Middleweek, B. Male homosocial bonds and perceptions of human-robot relationships in an online sex doll forum. Sexualities 2020. [CrossRef]

22. Döring, N.; Pöschl, S. Sex toys, sex dolls, sex robots: Our under-researched bed-fellows. Sexologies 2018, 27, e51-e55. [CrossRef]

23. James, K.B. 2040 Brad Armstrong, 2009. Porn Stud. 2017, 4, 353-360. [CrossRef]

24. Burr-Miller, A.; Aoki, E. Becoming (Hetero) Sexual? The Hetero-Spectacle of Idollators and their Real Dolls. Sex. Cult. 2013, 17, 384-400. [CrossRef]

25. Mariano Gomes, L.; Wu, R. User Evaluation of the Neurodildo: A Mind-Controlled Sex Toy for People with Disabilities and an Exploration of Its Applications to Sex Robots. Robotics 2018, 7, 46. [CrossRef] 
26. McArthur, N.; Twist, M.L. The rise of digisexuality: Therapeutic challenges and possibilities. Sex. Relatsh. Ther. 2017, 32, 334-344. [CrossRef]

27. Tay, B.T.; Low, S.C.; Ko, K.H.; Park, T. Types of humor that robots can play. Comput. Hum. Behav. 2016, 60, 19-28. [CrossRef]

28. Harper, C.A.; Lievesley, R. Sex Doll Ownership: An Agenda for Research. Curr. Psychiatry Rep. 2020, 22, 1-8. [CrossRef]

29. Eichenberg, C.; Khamis, M.; Hübner, L. The attitudes of therapists and physicians on the use of sex robots in sexual therapy: Online survey and interview study. J. Med. Int. Res. 2019, 21, e13853. [CrossRef]

30. Su, N.M.; Lazar, A.; Bardzell, J.; Bardzell, S. Of dolls and men: Anticipating sexual intimacy with robots. ACM Trans. Comput. Hum. Interact. (TOCHI) 2019, 26, 1-35. [CrossRef]

31. Langcaster-James, M.; Bentley, G.R. Beyond the Sex Doll: Post-Human Companionship and the Rise of the Allodoll. Robotics 2018, 7, 62. [CrossRef]

32. Döring, N.; Poeschl, S. Love and sex with robots: A content analysis of media representations. Int. J. Soc. Robot. 2019, 11, 665-677. [CrossRef]

33. Whitby, B. Sometimes it's hard to be a robot: A call for action on the ethics of abusing artificial agents. Interact. Comput. 2008, 20, 326-333. [CrossRef]

34. Chatterjee, B.B. Child sex dolls and robots: Challenging the boundaries of the child protection framework. International Review of Law. Comput. Technol. 2020, 34, 22-43. [CrossRef]

35. Brown, R.; Shelling, J. Exploring the implications of child sex dolls. Trends Issues Crime Crim. Justice 2019, 570, 1-13.

36. Ángel, I.T.; Casado, C.M. Simulaciones sexo genéricas, bebés reborn y muñecas eróticas hiperrealistas. Opción Rev. Cienc. Hum. Soc. 2016, 81, 189-212, ISSN 1012-1587.

37. Yulianto, B. Philosophy of information technology: Sex robot and its ethical issues. In Rapid Autom: Concepts, Methodologies, Tools, and Applications; IGI Global: Pennsylvania, PA, USA, 2019; pp. 1458-1467. [CrossRef]

38. Connor, S. Guys and Dolls. Women Cult. Rev. 2015, 26, 129-142. [CrossRef]

39. Frank, L.; Nyholm, S. Robot sex and consent: Is consent to sex between a robot and a human conceivable, possible, and desirable? Artif. Intell. Law 2017, 25, 305-323. [CrossRef]

40. Ess, C.M. What's love got to do with it? Robots, sexuality, and the arts of being human. In Social Robots; Routledge: London, UK, 2017; pp. 57-79. [CrossRef]

41. Brahnam, S.; De Angeli, A. Gender affordances of conversational agents. Interact. Comput. 2012, 24, 139-153. [CrossRef]

42. Danaher, J. Regulating Child Sex Robots: Restriction or Experimentation? Med. Law Rev. 2019, 27, 553-575. [CrossRef]

43. Headleand, C.J.; Teahan, W.J.; ap Cenydd, L. Sexbots: A case for artificial ethical agents. Connect. Sci. 2020, 32, 204-221. [CrossRef]

44. Fiske, A.; Henningsen, P.; Buyx, A. Your robot therapist will see you now: Ethical implications of embodied artificial intelligence in psychiatry, psychology, and psychotherapy. J. Med. Int. Res. 2019, 21, e13216. [CrossRef] [PubMed]

45. Nordmo, M.; Næss, J.Ø.; Husøy, M.F.; Arnestad, M.N. Friends, lovers or nothing: Men and women differ in their perceptions of sex robots and platonic love robots. Front. Psychol. 2020, 11, 355. [CrossRef] [PubMed]

46. González-González, C.S.; Gil-Iranzo, R.M.; Paderewski, P. Sex with robots: Analyzing the gender and ethics approaches in design. In Proceedings of the XX International Conference on Human Computer Interaction (Interacción '19); Association for Computing Machinery: New York, NY, USA; pp. 1-8. [CrossRef]

47. Prescott, T.J.; Lepora, N.; Verschure, P.F. A future of living machines? International trends and prospects in biomimetic and biohybrid systems. In Bioinspiration, Biomimetics, and Bioreplication 2014; International Society for Optics and Photonics: Bellingham, WA, USA, 2014; p. 905502. [CrossRef]

48. Prescott, T. The 'me' in the machine. New Sci. 2015, 225, 36-39. [CrossRef]

49. Moulin-Frier, C. DAC-h3: A proactive robot cognitive architecture to acquire and express knowledge about the world and the self. arXiv 2017, arXiv:1706.03661. [CrossRef]

50. Pointeau, G.; Dominey, P.F. The role of autobiographical memory in the development of a robot self. Front. Neurorobot. 2017, 11, 27. [CrossRef]

51. Reggia, J.A.; Katz, G.; Huang, D.W. What are the computational correlates of consciousness? Biol. Inspired Cogn. Archit. 2016, 17, 101-113. [CrossRef]

52. Levy, D. Intimate Relationships with Artificial Partners. Ph.D. Thesis, Maastricht University, Maastricht, The Netherlands, 2007.

53. Sullins, J.P. Robots, love, and sex: The ethics of building a love machine. IEEE Trans. Affect. Comput. 2012, 3, 398-409. [CrossRef]

54. Fong, T.; Nourbakhsh, I.; Dautenhahn, K. A survey of socially interactive robots. Robot. Auton. Syst. 2003, 42, 143-166. [CrossRef]

55. Dunne, D. Meet Silicon Samantha: AI Sex Robot Has a Functioning G-Spot and Can Switch Between 'Family' and 'Sexy' Mode. 2017. Available online: https://www.dailymail.co.uk/sciencetech/article-4331408/Sex-robot-Silicon-Samantha-functioningG-spot.html (accessed on 29 September 2020).

56. Available online: https:/ / ethicsinaction.ieee.org/ (accessed on 30 December 2020). 